\title{
Introduction: The Contradictions of Opposition to Free Trade
}

\author{
David Arditi
}

When both Bernie Sanders and Donald Trump featured anti-NAFTA (North American Free Trade Agreement) rhetoric centrally in their respective 2016 campaigns, it struck me how relevant this trade policy was to how people feel across the United States. Opposition to NAFTA is strong on the left and the right, and in a previous issue of Fast Capitalism, Scott McNall states:

There have been several mass demonstrations against the World Trade Organization (WTO), as well as the North American Free Trade Agreement (NAFTA). If you characterize the groups that show up to demonstrate in terms of left, right, conservative, or liberal, you have a hard time understanding people's motivations, because you will find members of conservative religious groups protesting right beside members of labor groups, farmers' cooperatives, environmental activists, etc. These disparate groups are, however, joined on the topic of individual freedom and autonomy, and often a desire to strengthen local and regional economies and cultures. Such groups would be seen as sources of real negativity, locking arms in the Great Refusal (McNall 2009).

The logic of opposition to NAFTA is clear on a political campaign, but the ripe fruit of opposition to it soon spoils when you try to understand the collective disagreement. In many ways, the debate over Brexit parallels these global forces. David Harvey links NAFTA and the European Union as attempts in the current capitalist regime to "reterritorialize" regions (Harvey 2006:105). Reterritorialization creates the opportunity for the capitalist class to generate more profit using reduced trade barriers to exploit labor. For Harvey, uneven capitalist development creates instability within state boundaries (Harvey 2006) and the state needs to reconfigure to create new enemies. The problem is that the impact of trade agreements on everyday lives quickly lends itself to scapegoating and xenophobia while the perpetrators of global inequality reap the benefits of animosity, disorganization, and apathy.

As a kid growing up in Virginia, I witnessed first-hand the devastation NAFTA wrought on communities that sustained themselves on the textiles industry (a topic Sandra Via covers in this issue). However, the gap between the opposition the Trump and Sanders campaigns displayed to NAFTA brought me back to a situation I experienced on former Rep. Rick Boucher's 2006 campaign for the U.S. House of Representatives.

Following a stint in Rep. Boucher's congressional office in Washington, D.C. as a legislative assistant (thanks to the Virginia Tech Graduate Congressional Fellowship), the Boucher Campaign recruited me as a field organizer after I returned to Blacksburg, VA. My experience with Boucher gave me first-hand knowledge about the Ninth Congressional District of Virginia and his position on certain issues. In 1993, Boucher was among the majority of Democrats who voted against NAFTA, and he remained opposed to the trade policy through his final term in Congress. While I worked on Capitol Hill, immigration was a heated topic, and we regularly received more than ten phone calls in a day from constituents about the topic. However, I did not realize how conflictual immigration was until I attended an event in New Castle, Virginia.

On a cool October night, I attended the Craig County Democratic Party's meeting in New Castle as a representative of the Boucher campaign. Upon arrival, the group's chair told me that she had been trying to reach Boucher to discuss a question she had about immigration. She informed me that she would ask me a question when I was addressing the group. Later, as I began addressing the group about the Boucher campaign, the chair interrupted. 
Chair: What is Rick [Boucher] doing about immigration?

Me (thinking I am addressing a group of like-minded Democrats who would be upset by Boucher's votes): Rep. Boucher voted with Republicans for a stronger border bill because he knew that the bill would never be signed into law ...

Chair: What?

Crowd: [groans of outrage]

Chair's husband: We need to do something about illegals [sic]. They are everywhere. If you go to Hardee's in Covington, they're there just hanging out every day. If you go to Blacksburg, where you live, they're everywhere.

Member \#1: We can't get jobs here, and the Mexicans [sic] are moving in and there are no jobs.

Chair: I can't believe he would not support a tougher border because it is what we need! We need to get rid of the illegals [sic], we're being overrun.

Me: I understand that Craig County suffers from economic decline, and there are no jobs here because factories closed. Those factories closed because of NAFTA. Rep. Boucher opposed the passage of NAFTA in 1993, and has fought hard against the trade pact and its effects ever since that day. NAFTA took away your jobs! [crowd relaxes]

Chair: I'm going to be following up with Rick.

Later, as I got into my car to go home, I had a slur leveled at my Honda Accord. ${ }^{1}$ The tensions in the room that day were palpable. The members of Craig County's Democratic Party were willing to blame the "other" for their lack of opportunity even though they knew that the driving force of their struggles was the result of a trade pact-a trade pact built to exploit the very people they harbored animosity towards. The Chair's husband leveled some vile statements about human beings, and his examples of Covington and Blacksburg were both about an hour from New Castle. In other words, to find blame in the "other," they had to connect their community to communities at least an hour's car drive away. Following this incident, I never had to drive to Craig County again because the Campaign Manager assigned a different field staff member to the county. It also struck me how an issue like immigration could be so contentious at a meeting of the Democratic Party—-the party I always connected with equality, respect for diversity, and the humanity of people. This meeting could easily signify the resilience of the old Democratic Party of the South (i.e., the segregationist party); after all, the Ku Klux Klan had marched in New Castle, VA less than ten years before this meeting. However, their recognition that NAFTA was the problem sustained another perspective; specifically, the tensions between NAFTA and Latinx immigration in rural America are closely knit together.

Craig County, VA is Trump country. The rural county embedded in the Jefferson National Forrest is over 98\% white and the population is just over 5,000 people. According to the Virginia Department of Election's website, out of 2,794 votes cast in 2016, Donald Trump received 2,140 (77\%) to Hillary Clinton's $541(19 \%)$ (Virginia Department of Elections 2016). The 1992 presidential election was much closer with George HW Bush receiving 1,008 votes (44\%) to Bill Clinton's 995 (42\%) (Virginia Department of Elections 1992). By the 2000 election, the surge of Craig County voters toward the Republican Party was substantial when George W Bush won 1,580 votes $(63 \%)$ to $\mathrm{Al}$ Gore's 851 votes (34\%) - a divide very close to the votes received by John McCain and Barrack Obama, respectively (Virginia Department of Elections 2000, 2008). The shift in Craig County, while part of an overall shift throughout the South from Democrats to Republicans, ${ }^{2}$ accelerated following the passage of NAFTA. Whereas President Bill Clinton received $42 \%$ of the vote in 1992, Hillary Clinton received only 19\% 24 years later. This is an oversimplification of the complexities in Craig County, southwestern Virginia, and the US as a whole, but the correlation is not without merit.

When Donald Trump promised to rip-up NAFTA (Corasaniti, Burns, and Appelbaum 2017), he tapped into seething animosity among the white working-class, underclass, and unemployed whom NAFTA left behind over the previous 22 years. However, Trump's opposition to the trade agreement had little to do with opposition to neoliberal trade policy, and everything to do with the threat of the "other." It was no different from Trump's presidential announcement in 2015, when Trump pronounced, "When Mexico sends its people, they're not sending their best. They're not sending you. They're not sending you. They're sending people that have lots of problems, and they're bringing those problems with us [sic]. They're bringing drugs. They're bringing crime. They're rapists. And some, I 
assume, are good people" (Trump 2015). What people often overlook is that this horribly racist statement is threaded into a discussion about trade deals. In fact, he mentions the word trade nine times and immigration only twice. Trump derides trade with China, Mexico, and Japan all while asserting that he is a "free trader," but a free trader who uses trade to put America's interests first. The logic will make your head spin, but the connection between NAFTA and immigration is clear. However, "one of NAFTA's central intended effects is to increase the hegemonic power of the American economy in the region” (Smith 1997:42). From Smith's perspective, Trump's desire to renegotiate NAFTA is firmly in line with the original intent of the act.

As Sagar Deva and Denisa Krásná outline in this issue, NAFTA and immigration are linked clearly, but not in the way Trump imagines. Rather, neoliberal forces unleashed by NAFTA restrict the movement of people (specifically Mexicans), while permitting goods, capital, and ideas to move with few barriers. To comply with NAFTA, the Salinas regime in Mexico eliminated its ejido land system, which forced peasants to either join the factory workforce or migrate to the US (See Sagar and Krásná this volume; Harvey 2005:101). In effect, NAFTA created cheap labor in Mexico, while restricting that labor from legally migrating north. People flee the oppressive labor conditions in Mexico, but the migrants who then arrive in the USA do not have recourse to labor laws because of their undocumented status; thereby further subjugating them to the harsh forces of neoliberal trade. Trump's rhetoric taps into a xenophobia that exists among many whites in the USA but does nothing to alleviate the structural problems that actually cause harm to all people on both sides of the US-Mexico border. The (im)mobility of immigrants highlights the structural problems of globalization. "Migrants demonstrate (and help construct) the general commonality of the multitude by crossing and thus partially undermining every geographical barrier" (Hardt and Negri 2004:134). While NAFTA attempts to exploit cheap labor in Mexico, it ejects people from their communities and unleashes the very opposition to globalization. Even though immigrants are forced from their communities by NAFTA, the supporters of NAFTA are "simultaneously stirring up xenophobic hatred towards the disenfranchised laborers who try to traverse these borders into the United States" (Kaye 2016). At the same time, NAFTA frees the wealthy to move and communicate across borders. "Trade agreements such as NAFTA have eased restrictions on corporate and business executives, professionals, and highly skilled workers as they move from one country to another" (Goldman, Papson, and Kersey 2006). In fact, the wealthy "transnational capitalist class" in Mexico, Canada, and the US led the passage of NAFTA (Sklair 2001:101-5). These contradictions generate a lot of animosity towards free trade, and NAFTA in particular, but rarely see the exploitative origins of the paradoxes.

In a recent issue of Rolling Stone magazine, the strange contradictions created by opposition to NAFTA become visible. Since Rolling Stone is a proud lefty magazine, the editors take every opportunity to stick it to Donald Trump. Josh Eells' article, "Why We Need Mexico," highlights the extent to which the left (and I do not mean moderate Democrats) finds it difficult to parse the contradictions of opposing NAFTA. As an attempt to lay bare Trump's xenophobic immigration policies and his desire to build a border wall using a national emergency declaration, Eells demonstrates that the vibrancy of McAllen, Texas is largely a result of Mexico and Mexicans (Eells 2019). The general idea is that McAllen has a larger tax base per capita than most places in Texas because Mexicans (legally) travel across the border to shop, which the locals call in Spanish "macalenear, or literally 'to do McAllen"” (Eells 2019:50). Since Texas generates most of its tax revenue from sales taxes, this is a boon for McAllen. This is a comforting perspective, we need Mexico because Mexicans come to the US to shop; however, the article becomes decidedly darker from there.

Eels interviews Keith Patridge, the CEO of the McAllen Economic Development Corporation, a group that operates much like a local Chamber of Commerce. Patridge describes himself as a tax cut-loving, Trump-voting Republican who "believes Trump's stance toward Mexico is counterproductive" (Eells 2019:51). It turns out that Patridge's group used the McAllen free trade zone to market Reynosa, Mexico instead of McAllen, Texas to the transnational capitalist class. Reynosa is the much larger sister city to McAllen that sits just across the Rio Grande. After the implementation of NAFTA:

\footnotetext{
according to Patridge, the average wage in the maquiladoras just across the border in Reynosa was about 80 cents an hour — and because of the rapid devaluation of the peso, in a few months it was headed down toward 35 cents. "So I said, 'I know what will attract companies here," Patridge recalls. "It's not McAllen - it's that 35-cents-an-hour labor rate, right across the river from the largest market in the world" (Eells 2019:51).
}

Factories moved from other parts of the United States to open maquiladoras in Reynosa and exploit a comparative advantage on wage rates. The benefit that Patridge sees is that the factories could move to Reynosa and 
the engineers and managers can live in McAllen. The article describes a form of apartheid where wealthy Americans can drive across the Rio Grande to exploit cheap labor, then return to America to live each night. Of course, the cheap Mexican labor does not receive the same rights to work in America for a higher wage and commute back to Mexico at night. Here, the reality of how "la Frontera" is not the US, or Mexico, but its own liminal space where, as some say money marks the border. The article ends up supporting NAFTA as a windfall for McAllen and cheap goods for Americans, but underneath is raw exploitation.

In late March 2019, Trump threatened to close the US-Mexico border and highlighted some of the problems with claiming to be a "free trader" in-chief at the same time that he is lauded by white nationalists as the xenophobein-chief. The reaction to closing the southern border from people of most political persuasions was swift, and the debate about the border turned quickly toward the impact on the economy (Paletta and Dawsey 2019)—especially to avocados. Before Trump backpedaled entirely to a warning for Mexico to slow the "flow of drugs and migrants into the United States" (Sonmez 2019), there was much ink spilled on the economic impact of closing the southern border. One idea was to continue to allow trains and trucks to cross the border (Paletta and Dawsey 2019) - note this would do little to alleviate drugs or people crossing the border. This highlights that the threat was more spectacle than substantive-Trump wanted to gin up his base, which has always supported him because of his regressive views on immigration.

In fact, the new United States-Mexico-Canada Agreement (USMCA) designed to replace NAFTA points to the spectacle of Trump's presidency. Since he promised to eliminate NAFTA and renegotiate a "great deal" because he says the US is "losing" as a result of NAFTA, he followed through by creating USMCA. Yet there is little difference between the USMCA and NAFTA except for a couple of points where Trump thinks the US lost. Instead of focusing on the details of this deal here, I think it is important to state that the agreement changes very little. In fact, one major opposition to the bill comes from Democrats who want to see labor laws strengthened in Mexico to support workers at home and in Mexico (Mauldin 2019). This was always the problem with NAFTA—it created free trade with Mexico thereby allowing things to be made cheaply by exploiting cheap labor across the border and importing those goods back into the United States without tariffs-and it was the reason why the three North American countries created the agreement in the first place. Here Trump tangled himself in a knot of promises that do not speak to the problems experienced by those who oppose NAFTA. I have come to think that when Trump claims to be "the best" dealmaker (and liberals laugh at him), he speaks to the deals that he made to his voters, not the great deals he will make as president. Deal-making is transactional politics to Trump. This is a weird rhetorical twist because he views deals not as outcomes of negotiations, but rather as giving one group of people what they want in return for him gaining power or money. However, he caught himself in a Faustian bargain by promising to get rid of a trade agreement he (and the GOP) strongly support - again, in his own words he is a "free trader" (Trump 2015). In order to save face, and claim that he eliminated it, he has conducted a charade of "tearing up" NAFTA and replacing it with something "great," but the USMCA looks exactly like the original agreement. He bets that he can eliminate NAFTA and run for reelection on it before some white working-class voters realize the deal did not improve their lives.

By interrogating NAFTA, USMCA, and Brexit, we hope that this issue of Fast Capitalism provides policymakers, academics, and the public with some intellectual heft to think about the implications of these policies on people. Too often capitalists and corporations set the field of debate about these policies through think tanks and the press. "The ideas of the ruling class are in every epoch the ruling ideas, i.e., the class which is the ruling material force of society, is at the same time its ruling intellectual force" (Marx 1978:172). The goal of this special issue is to provide a counterhegemonic intervention on the discourse about NAFTA, USMCA, and Brexit. When Trump opposes NAFTA in support of something better, he does so by blaming Mexico and Mexicans for all the problems that poor and working-class whites face in the United States. His solution is to make the other pay through arbitrary xenophobic means. The ruling class perpetuates racial/ethnic divisions as an ideological means to obscure the true direction of exploitation of trade pacts. We hope that the readers recognize that the debates about these policies are in motion. To wait until after the dust settles would make more accurate accounts of the policies, but this would miss the opportunity to offer a counter-narrative. We welcome lively debate about these issues.

This special issue on NAFTA and Brexit begins by exploring Neoliberalism. Specifically, Henry Giroux explains that underlying Neoliberalism is a fascist tendency to squash democracy. Giroux lays out the theoretical underpinnings of populist authoritarianism in which citizens internalize neoliberal logic that leave subjects powerless to the economy. This faux populism provides the support for leaders to remake international policies (ex. NAFTA and Brexit) that further disempower and exploit people. 
Sandra Via provides a first-hand account of the devastation caused by NAFTA in "Twenty-Five Years and Still Recovering: A Brief Reflection on NAFTA's Impact on Southside, Virginia." In this polemic, Via provides important on-the-ground details about life in rural Virginia after NAFTA. Sagar Deva and Denisa Krásná move the discussion of NAFTA from the United States to Mexico and describe the dehumanization of life in Juarez, Mexico in "Neoliberalism, NAFTA, and Dehumanization: The case of femicides in Ciudad Juárez." Deva and Sagar demonstrate the social, cultural, political, and economic changes that happened because of NAFTA and have resulted in femicides. In "Abject Futures: The (re)Negotiation of NAFTA and the Canadian Power Elite," Dean Ray takes the discussion north to Canada. Ray's essay moves the issue from those exploited by free trade agreements to those who benefit. He argues that Canada negotiated the USMCA agreement to benefit Canadian economic elites.

In "Taking Back Control of Nothing: Elites Denouncing Elites to Mobilize Populism in the Service of Power - from NAFTA to Trump, Brexit, and the EU," Christian Garland demonstrates the similarities between Donald Trump and the Brexiters. Garland's article helps straddle the discourse between NAFTA and Brexit. The issue concludes with Paul Smith's “The Antinomies of Brexit." By exploring the left-right tensions over inclusion in the European Union and the European Economic Community, Smith shows that the history of British inclusion in the Europe Union has been fraught for complex reasons from the start. Furthermore, Smith connects some of the themes over fake populism started in Giroux's article. Smith's essay not only explores the specificities of Brexit but places this within the colonial legacy of Britain. All discussions of free trade stand in the shadow of colonialism.

\section{New Times, Marxism Today, and the Public Intellectual}

During the Thatcher era in the United Kingdom, scholars associated with the Birmingham School of Cultural Studies published a series of essays in Marxism Today trying to make sense of Thatcherism while her policies began to wreak havoc on British people. Their project aimed to reimagine the Left in what they called "New Times," Stuart Hall and Martin Jacques later published this series in a volume by the same name (Hall and Jacques 1989). While Hall et al. tried to make sense of Thatcherism, they began describing in real time the policies and logics of what we now call neoliberalism. The subtitle of New Times: The Changing Face of Politics in the 1990s pointed toward the future because Hall and Jacques published the volume in 1989.

As I assume duties as Editor of Fast Capitalism, Timothy Luke and I would like to take the journal in a direction that regularly allows commentary from academics on the current moment. Of course, this is something that Ben Agger and Luke always committed as part of the mission of the journal. In 2007, Agger and Luke published a special issue (3.1) on the tragedy at Virginia Tech that went from idea to publication in the same year as the shooting. This serves as a model on which we can build special calls for papers/proposals to comment on the changing world of fast capitalism (Agger 1988). While conventional journal formats often have a lag between acceptance and publication (even longer for print publication), these restrictions do not apply to the online format of Fast Capitalism.

Please look for our special calls. Sometimes these may be short issues with short timelines (like the present issue), while other times they may call for more cerebral analyses of changing structures. In any case, we hope to provide a forum for intellectual discourse and discussion about issues that impact the structure of society.

\section{Endnotes}

1. Coincidentally, in terms of global trade, Honda Accords have been made in Marysville, $\mathrm{OH}$ since 1982, so my car was, in fact, "American Made." This is similar to Toyota Tundras, which to clarify the point, include stickers that read "Born in Texas, Built by Texans" emblazoned on a Texas flag.
2. Furthermore, the southern shift from Democrats to Republicans in federal politics predates this shift by 1020 years. 


\section{References}

Agger, Ben. 1988. Fast Capitalism. Urbana, IL: University of Illinois Press.

Corasaniti, Nick, Alexander Burns, and Binyamin Appelbaum. 2017. "Donald Trump Vows to Rip Up Trade Deals and Confront China." The New York Times, December 21.

Eells, Josh. 2019. “Why We Need Mexico.” Rolling Stone, February, 49-52.

Goldman Robert, Stephen Papson, and Noah Kersey. 2006. "Landscapes of the Social Relations of Production in a Networked Society." Fast Capitalism 2(1).

Hall, Stuart and Martin Jacques, eds. 1989. New Times: Changing Face of Politics in the 1990's. Stated First Edition edition. London: Lawrence \& Wishart Ltd.

Hardt, Michael and Antonio Negri. 2004. Multitude: War and Democracy in the Age of Empire. New York: The Penguin Press.

Harvey, David. 2005. A Brief History of Neoliberalism. Oxford; New York: Oxford University Press.

Harvey, David. 2006. Spaces of Global Capitalism. London ; New York, NY: Verso.

Kaye, Bradley. 2016. "Biopolitics and the Infected Community: Foucault, Sartre, Esposito, and Butler." Fast Capitalism 13(1).

Marx, Karl. 1978. “The German Ideology.” Pp. 146-200 in The Marx-Engels reader, edited by R. C. Tucker. New York: Norton.

Mauldin, William. 2019. “Trump's New Nafta Faces Mounting Resistance in Democratic House.” Wall Street Journal, April 28.

McNall, Scott G. 2009. "The Good, the Bad and the Ugly: A Retrospective on Telos." Fast Capitalism 5(1).
Paletta, Damian and Josh Dawsey. 2019. "White House Looks to Minimize Economic Impact of Trump's Threatened Closure of Mexico Border." Washington Post, April 2, Online.

Sklair, Leslie. 2001. The Transnational Capitalist Class. Oxford, UK ; Malden, Mass.: Blackwell.

Smith, Paul. 1997. Millennial Dreams: Contemporary Culture and Capital in the North. London ; New York: Verso.

Sonmez, Felicia. 2019. “Trump Backs off Threat to Close Southern Border Immediately, Says He'll Give Mexico 'One-Year Warning' on Drugs, Migrants.” Washington Post, April 4, Online.

Trump, Donald. 2015. "Full Text: Donald Trump Announces a Presidential Bid.” Washington Post, June 16, Online.

Virginia Department of Elections. 1992. "Election Results." Virginia Department of Elections. Retrieved April 2, 2019 (https://www.elections.virginia.gov/resultsreports/index. html).

Virginia Department of Elections. 2000. "Election Results." Virginia Department of Elections. Retrieved April 2, 2019 (https://www.elections.virginia.gov/resultsreports/index. html).

Virginia Department of Elections. 2008. "Election Results." Virginia Department of Elections. Retrieved April 2, 2019 (https://www.elections.virginia.gov/resultsreports/index. html).

Virginia Department of Elections. 2016. "Election Results." Virginia Department of Elections. Retrieved April 2, 2019 (https://www.elections.virginia.gov/resultsreports/index. html). 